\title{
Being Lister: ethos and Victorian medical discourse
}

\author{
J J Connor, ${ }^{1}$ J T H Connor ${ }^{2}$
}

${ }^{1}$ Division of Community Health and Humanities, Faculty of Medicine, Memorial University of Newfoundland, St John's, Canada; ${ }^{2}$ John Clinch Professor of Medical Humanities and History of Medicine, Faculty of Medicine, Memorial University of Newfoundland, St John's, Canada

Correspondence to: Jennifer J Connor, Division of Community Health and

Humanities, Faculty of Medicine, Memorial University of

Newfoundland, St John's,

Newfoundland, Canada A1B

3V6;

jennifer.connor@med.mun.ca

Accepted 26 February 2008

\section{ABSTRACT}

Stylistic analysis and rhetorical theory are used in this study to inform our understanding of impediments to the successful uptake of a new medical idea. Through examination of the work of the Victorian surgeon Joseph Lister, who was described by one biographer as suffering from "stylistic ham-handedness", the study provides insights into the difficulty that Lister had in explaining his theory of antiseptic surgery. Using three comparisonsLister's scientific style in public discourse with that of his students, and Lister's scientific style in private discourse with those of both a surbordinate and a superior - the study suggests that the rhetorical concept of ethos played a major role in his communication difficulties. In this way, it presents a more nuanced perspective on modern presentations of "model" communications versus communication failures: that is, that problematic written discourse offers as useful a heuristic device as does exemplary discourse.

Soft lines of tranquil thought his face fulfilHis face at once benign and proud and shy.

We hold him for another Herakles,

Battling with custom, prejudice, disease,

As once the son of Zeus with Death and Hell. ${ }^{1}$

These lines from the poem The Chief capture the heroic essence of Joseph Lister for many of his patients. But as they imply, among his medical colleagues this 19th-century British surgeon had faced widespread criticism for his antiseptic method of wound treatment based entirely on an as-yet-underdeveloped and little understood germ theory of disease. The method remained controversial for decades, until aseptic technique made it superfluous. The subsequent historiography, written mainly by Lister's surgical contemporaries and identifying him as the great Victorian innovator battling against ignorant detractors, has been challenged lately by less hagiographic and more critical historical assessments. While still recognising Lister's place in history, medical historians strive to contextualise his contributions against the background of 19th-century laboratory science and clinical practice. Now we can more fully appreciate that antiseptic surgery based on the liberal use of carbolic acid was "difficult, cumbersome and timeconsuming"; it was also more expensive than other approaches to wound management at the time (Granshaw, ${ }^{2}$ pp23, 30). At a theoretical level, too, Listerism was problematic; only with the benefit of historical gymnastics can we conclude that the scientific fundamentals espoused by Lister and his followers were "correct". The original germ (Pasteurian) theory of the mid-Victorian era was not really a theory at all; rather it was a series of hypotheses that in the long run morphed into something very different by the end of the 19th century, thanks to the bacteriological researches of Robert Koch. Advocates of antiseptic surgery/ Listerism were then, as Christopher Lawrence and Richard Dixey explain,

obliged to endorse German theory in order to continue representing themselves as being at the forefront of scientific medicine. Thus the tradition which credits Lister with tenacious commitment to a germ theory of disease in face of opposition disguises the fact that the germ theory which was finally and generally accepted by the medical community was quite unlike Lister's original theory (p156). ${ }^{3}$

Compounding the clinical and theoretical issues were issues of communication. Lister was partly to blame for this state of affairs, for he was a poor writer. He introduced the reason for his complicated treatment method, the destruction of harmful bacteria, at the end of his fivepart paper "On a new method of treating compound fracture, abscess, etc., with observations on the conditions of suppuration", published in The Lancet in 1867. "To what extent was this peculiar reticence scientific", one of Lister's biographers, Richard Fisher, astutely asks, "and what part was sheer stylistic ham-handedness?" (p146). ${ }^{4}$ Fisher's answer briefly focused only on Lister's acknowledged flatness of expression. Of all Lister's biographers, Fisher paid most attention to his publications and correctly observed that he wrote to instruct, not to theorise-in keeping with contemporary medical communication-but that he had difficulty arranging his thoughts (p145). ${ }^{4}$

To consider whether Lister's style was hamhanded, Connor and Connor examined a crucial element in his communication, the semantic concept of antiseptics. ${ }^{5}$ In use since 1712, this term was familiar to doctors, for whom it generally meant that wounds would be cleaned of decayed tissue by some antiseptic fluid (from the Greek meaning "against" "putrefaction"). A modern definition of "antiseptic" includes the notion of a substance that inhibits the growth and development of micro-organisms but does not necessarily kill them. We are in part indebted to Joseph Lister today for this later interpretation, for in 1867 he used the word antiseptic in what was then a new conceptual framework, a nascent germ theory of disease. In this view, the antiseptic fluid destroyed the bacteria that caused the decay of tissue. In his publications, Lister thus had cloaked his new concept in a familiar word, downplaying its radical nature but thereby confusing his readers around the world. Some, like William Canniff in Canada, 
maintained that Lister was egotistical in trying to claim novelty where there was none. ${ }^{6}$

It is clear, as Fisher suggests, that Lister's inability to explain his surgical innovation slowed acceptance of his method. Indeed, Lister's friends, colleagues, students and biographers routinely remarked on his problem communicating, and Lister himself referred many times to his discomfort in giving public addresses, engaging in debates over his methods, or writing for publication. Frequently observing that he had been misunderstood, he declared in 1875 that "it seems to be a difficult thing for me to write the English language so as to make my meaning intelligible" (p147). ${ }^{4}$ Perhaps not surprisingly, then, as Michael Worboys recently noted, contemporary surgeons experienced difficulty "translating [Lister's] words into action" (p83). ${ }^{7}$ Those who did adopt his method learnt from him directly, in surgery and on his wards; they became his disciples, training others around the English-speaking world.

Joseph Lister was therefore neither a "model" communicator in medicine nor a typical one. For these reasons, his is a complex case that lends insight into the process of writing for medical publication. As we will show, his difficulty embraced both semantic and syntactic problems: not only had he employed a familiar word to describe a novel concept-having his intended meaning bypass in the medical reader's mind-but his writing also held significant syntactic impediments for readers to understand and adopt his procedure. More important, both his semantic and syntactic difficulties stemmed from an underlying rhetorical struggle with ethos.

Our highlighting of biomedical writing in this paper adds to the new historiography of Listerism, but it also addresses the underexplored role of communication in the innovationdiffusion process of medical technology (Banta, ${ }^{8}$ p76). As two recent collections of essays on medical innovation attest, historical case studies contribute much to our understanding of the problems facing "adopters" and "resistors" of innovations with respect to such issues as risk, professional prestige, costs and social benefits. ${ }^{9}{ }^{10}$ As these studies, along with our own, demonstrate, the reason why clinicians understand/ misunderstand/accept/reject new medical knowledge, techniques, technology or processes is far more nuanced and complex than is generally recognised. Social factors or aspects of the "humanities" broadly construed, such as communication, may be as important in the uptake and diffusion of new medical knowledge as more obvious scientific or technical matters.

We therefore analyse Lister's style in different genres and from several perspectives:

- his scientific style in public and private discourse

- his scientific style compared with that of his own students in public discourse

- his scientific style in private correspondence with a subordinate and with a superior.

Two excerpts of the same word length (approximately 350 words) were chosen from Lister's writing for medical practitioners in two genres (article and letter). These excerpts present a description of a process, involving instructions for antiseptic wound dressing. Over the past few years, one of us has presented these two excerpts as a graduate course exercise to working professionals in biomedical communication. Trained in clinical subjects and typically employed as medical writers and editors, these modern readers corroborated our inferences about Lister's writing. Excerpts on antiseptic procedure from the publications of physicians who actually trained with Lister were then chosen for comparison with Lister's descriptions. Finally, an excerpt from one of Lister's personal letters on the topic was selected for comparison with his writing for medical readers.

\section{JOSEPH LISTER AND COMMUNICATION}

The surgeon Joseph Lister, the son of Joseph Jackson Lister, was born in England in 1827. In that year, his father published a seminal article in what is now the field of histology, and, as one historian has noted, JJLister's development of a reliable, powerful optical lens revolutionised medical training, diagnosis and research through use of the microscope; JJLister has therefore been deemed historically the "father of microscopical theory". ${ }^{11}$ By faith, he and generations of the Lister family belonged to the Society of Friends. Joseph Lister therefore was deeply influenced by the scientific and religious atmosphere in his home; indeed, a noted contemporary attributed his "sobriety of expression" and "self restrained statements" to his Quaker faith and heritage (Fisher, ${ }^{4}$ p147). One of Lister's house surgeons emphasised his humility, as evidenced by the fact that he had chosen to work as an assistant to a medical leader (James Syme) even after he was a fully qualified surgeon himself:

Let any of my professional readers recall their early qualified days, the confidence they had in their opinions and their frequent irreverence for the works and ways of their seniors,

John Rudd Leeson observed,

it was only experience that mellowed them. Fancy an F.R.C.S. attending to the out-patient casualties. Probably no one but Lister ever did it (p57). ${ }^{12}$

It is also worth recalling that even before this time, Lister could not attend the medical schools of traditional universities (Oxford and Cambridge) because of his dissenting faith from the Church of England: he attended the new non-denominational University of London.

Beyond just his upbringing and his faith, however, Lister appears to have been painfully shy: he reportedly had a slight stammer and experienced great nervousness when speaking publicly. ${ }^{42-15}$

Biographies of Joseph Lister must be used with caution, since they do not always rely on first-hand evidence and are often adulatory-and sometimes draw information from earlier biographies. ${ }^{16-18}$ Nevertheless, there seems to be agreement that students and colleagues learnt from him orally, not from his writings, and that this was the best way to learn his antiseptic technique: "we learnt nothing of the revolution from the printed page", one former student recalled, astonished after Lister's death to see the amount he had actually written (Leeson, ${ }^{12}$ p99). Hence, he suggested, foreigners successfully used his method where his countrymen did not, since they relied on light reading and discussion at medical societies (p127). ${ }^{12}$

This is not to say that Lister was unable to communicate in a variety of ways: he often lectured in German or French (and sometimes in Latin) for the benefit of his foreign students and visitors (Thomson, ${ }^{15}$ p100; Cameron, ${ }^{19}$ pp6-7). Although he once indicated, "I am by disposition very averse to quarrelling and contending with others" (Godlee, ${ }^{14}$ p31), when faced with published challenges from the medical community he responded in print. On one occasion, Lister's father thus chastised him about engaging in a print battle over the theories of his mentor, Symes: the senior man was big enough to fight for himself, he told him (Walker, ${ }^{18}$ p35). "Well, gentlemen," Lister would apparently tell students, "it is no new thing for me to be 
misunderstood" (Leeson, ${ }^{12}$ pp46, 124). By socialisation, faith and temperament, then, Lister seemed resigned to encounter difficulty communicating the novelty and merits of his antiseptic wound management to the medical community. Examination of his writing style reveals more precisely the nature of his difficulty.

\section{LISTER'S SCIENTIFIC STYLE IN PUBLIC DISCOURSE}

Lister's father apparently urged him to publish (Fisher, ${ }^{4}$ p113). Although he was slow to react, perhaps this constant encouragement explains why he initially published 15 papers in 3 years, from 1857 to 1860 . He published only four papers between 1860 and 1867, and of the 13 published in the postantiseptic era after 1867 and his father's death in 1869, Fisher notes that most were defensive (pp83, 98). ${ }^{4}$ Lister's inability to write a treatise on his technique meant that others from 1871 to 1876 published books on antiseptic surgery, Fisher remarks, "doing what Lister would not do" (pp203-4). ${ }^{4}$

Biographers have noted that Lister found it exhausting to write, as he "painfully considered the exact meaning of every word" (Godlee, ${ }^{14}$ p185). Absorbed by his clinical work, he procrastinated in preparing lectures and public talks and often left them to the very last minute. His drafts underwent much revision but were still so long that his papers were published in parts. Fisher notes further that Lister constantly shifted

\section{Box 1: Joseph Lister's writing}

When, however, the wound is very large, the flow of blood and serum is so profuse, especially during the first twenty-four hours, that the antiseptic application cannot prevent the spread of decomposition into the interior unless it overlaps the sound skin for a very considerable distance, and this was inadmissible by the method described above, on account of the extensive sloughing of the surface of the cutis which it would involve. This difficulty has, however, been overcome by employing a paste composed of common whitening (carbonate of lime) mixed with a solution of one part of carbolic acid in four parts of boiled linseed oil, so as to form a firm putty. This application contains the acid in too dilute a form to excoriate the skin, which it may be made to cover to any extent that may be thought desirable, while its substance serves as a reservoir of the antiseptic material. So long as any discharge continues, the paste should be changed daily; and, in order to prevent the chance of mischief occurring during the process, a piece of rag dipped in the solution of carbolic acid in oil is put on next the skin, and maintained there permanently, care being taken to avoid raising it along with the putty. This rag is always kept in an antiseptic condition from contact with the paste above it, and destroys any germs which may fall upon it during the short time that should alone be allowed to pass in the changing of the dressing. The putty should be in a layer about a quarter of an inch thick, and may be advantageously applied rolled out between two pieces of thin calico, which maintain it in the form of a continuous sheet, that may be wrapped in a moment round the whole circumference of a limb, if this be thought desirable, while the putty is prevented by the calico from sticking to the rag which is next the skin. When all discharge has ceased, the use of the paste is discontinued, but the original rag is left adhering to the skin till healing by scabbing is supposed to be complete. (Lister $\mathrm{J}$. On the antiseptic principle in the practice of surgery. Read before the British Medical Association in August 1867 and published in the British Medical Journal 1867;ii: 246 (from Lister, ${ }^{20}$ pp38-9).) direction in his writing and could not assign priority to topics (pp147, 187). ${ }^{4}$ Indeed, he took 3 years to publish a clear statement that Fisher suggests should have introduced his first paper-and even then, Lister placed the statement in a footnote (pp145-6). ${ }^{4}$

Scrutiny of even a single passage from Lister's published work confirms Fisher's inferences about its lack of focus and direction and also allows deeper insight into reasons for his difficultiesespecially in comparison with contemporary writers and, later in this discussion, with his own writing in different genres.

The excerpt in box 1 forms only part of a long paragraph from an article in the British Medical Journal in 1867, in which Lister attempts to describe how to bandage a compound fracture with his antiseptic dressing. ${ }^{20}$ Surrounding this passage is Lister's leisurely discussion in which he refers to himself and addresses his readers: "I have at present in the hospital a man with severe compound fracture of both bones of the left leg"; "We cannot, however, always calculate on so perfect a result as this"; "And here I would desire earnestly to enforce the necessity of persevering with the antiseptic application"; "I cannot, however, expect my professional brethren to follow my advice blindly in such a matter"; and so on. In these ways, his writing has a narrative quality and immediacy suitable for an oral presentation. When Lister shifts to explanation of his methods, however, his writing becomes more diffuse.

Clearly, even the portion of a paragraph in box 1 demonstrates lack of control and coherence. The sentence structure is convoluted: most of the seven sentences have subordinate clauses, some of them several, and two sentences each contain more than 70 words. Lister constantly interrupts his thought process. Although sentences often open with the subject and verb, they meander through inserted clarifications, making it very difficult to track his ideas (most noticeable in the two longest sentences beginning "When, however," and "The putty should be in a layer").

Lister also uses many participles; and, what is even more problematic, he relies on the verb "to be" in its various forms (including passive construction). When this verb appears in its role as a copula, his sentences lack clarity: in modern terms, he avoids action statements by avoiding action verbs. The first sentence is a prime example of this use of "to be" as a copula: "When the wound is very large ... the flow of blood and serum is so profuse ... that ... ". It seems the whole sentence is hanging on that little verb is (or is it?). Yet when he implicitly invokes the germ theory of disease, he suddenly becomes active: "This rag ... destroys any germs which may fall upon it." Such a powerful verb destroys embedded in an otherwise fuzzy discussion betrays his primary message: that germs cause infection, and it is therefore germs, not rotted flesh, that one must destroy.

Lister's word choice lacks clarity, particularly for the explanation of a procedure. He does not identify quantities or sizes (except for the putty, which should be a quarter of an inch thick). He uses vague intensifiers (very, so) that also demand interpretation. In fact, he leaves much up to the reader to interpret: "may be advantageously applied"; "if this be thought desirable". His use of common materials (rag, calico) also lacks precision, and his only nod to technical language seems to be cutis, and perhaps excoriate. Some of the vagueness in this passage may be attributed to his deference to colleagues and his recognition of unique circumstances of each wound in their care. But its overall effect is to render the communication tentative and unconvincing. 


\section{Box 2: Frederick Le Maitre Grasett's writing}

The mode of procedure summed up is as follows:-The skin being cleansed, the fingers of the surgeon and assistants, sponges, knife, and all instruments used purified; the spray is turned on, the opening made, the pus evacuated, any bleeding vessel secured by a carbolised catgut ligature, the ends of which are cut short off close to the knot, and then a piece of drainage tube (to allow no serum to lodge in the cavity, else tension would result, causing inflammation,) introduced, the dressing of gauze applied and secured with a bandage. As soon as it becomes necessary to change this dressing, (which it is always well to do after 24 hours), an assistant should place his hand over the dressing while the pins with which the bandage has been fastened to it are removed and the bandage cut; this side of the dressing is then carefully raised and the spray directed into the angle between the dressing and the wound; the drainage tube is removed, washed in 1-40 lotion and re-introduced, the skin washed and a fresh dressing applied. By degrees the intervals between the dressings become longer, thus every $2,3,4,5$, or 6 days, as required by the diminished amount of discharge, at the same time shortening the drainage tube as required. The drainage tubing is that used by M. Chassaignac, and has holes cut in the side to allow the discharge to reach the lumen of the tube.

In all operation cases in which the skin is unbroken this is the mode of procedure, but in accidental wounds, such as compound fractures, dislocations not requiring amputation, we have to remember that septic matter has gained admission to the wound before we saw it, and we have to endeavor to correct it by thoroughly washing out the wound with a strong watery solution of carbolic acid, taking care that the solution penetrates into all the recesses of the wound, of course also removing all foreign bodies and pieces of bone. To shield the wound from the irritating action of the carbolic acid, it is necessary to use some material that will be practically impervious to carbolic acid, and nonirritating itself. A very satisfactory protection is made by coating oil-silk with copal varnish and then a layer of dextrine. The dextrine allows the oil-silk to become uniformly wetted by the antiseptic solution (otherwise it would glide off the silk like water off a duck's back) into which it is dipped at the time of application to the wound. For if the carbolic acid was not kept from irritating the wound, healing would not take place and the tissues would be stimulated to suppurate. (From Grasett F LeM, ${ }^{21}$ pp103-4.)

That Lister's style was not merely contemporary but his own becomes clear in comparison with instructions for antiseptic dressings written by those who trained with him. Boxes 2 and 3 are similar-sized excerpts taken from the writing of two of the many "foreigners" who travelled to Great Britain to study Lister's technique: Frederick Le Maitre Grasett and Thomas Roddick, who both became prominent surgeons in Canada. A rudimentary statistical comparison of the Lister example with these two excerpts suggests that his syntactic structure is not anomalous, either for the times or the subject matter. His average number of words per sentence, average word length and even maximum number of words in a sentence superficially would not indicate that he writes any more diffusely than his medical colleagues; indeed, one of Grasett's sentences (table 1) is far longer than Lister's longest sentence.

However, even a glance at the writing of his followers shows structural differences that greatly aid readability. Unlike Lister, each writer reported antiseptic procedures succinctly and accurately

\section{Box 3: Thomas Roddick's writing}

I proceeded as follows:-The steam spray producer being directed over the part, I first injected by means of a catheter a one-to-five spirit solution of carbolic acid into every crevice of the wound and between the broken bones, as a large quantity of gravel and filth had been ground into the part by the accident, and placed there by his fellow-labourers with the view of arresting hæmorrhage. I then washed the entire foot thoroughly with a oneto-twenty carbolic solution, being especially careful to cleanse the clefts between the toes, which, by-the-way, were much bruised and lacerated. A piece of the largest size (No. 1), drainage tube, employed by Mr. Lister, was now carried to the bottom of the wound, having been first soaked in the one-to-twenty solution and armed with wires at its mouth to keep it more steadily in position. The angles of the wound were brought together with cat-gut sutures, oil-silk protective, dipped in one to forty, of size sufficient to cover the wound was applied, and over this a double layer of antiseptic gauze soaked in the one to forty carbolic solution. The lacerated wounds across the dorsal surfaces of the toes, were also covered with the protective and wet gauze, and then the entire foot and lower leg were enveloped in a dressing consisting of eight layers of gauze with a piece of macintosh cloth, on "hat lining" interposed between the seventh and eighth layer. The dressing was held in position by a gauze bandage, and the limb placed in a box splint. Brandy and milk were ordered to be given at stated intervals. A "draw sheet" was placed beneath the limb, as it lay in the box, for the purpose of indicating any discharge. (From Roddick, ${ }^{22}$ pp242-43.)

Unlike the portion of Lister's long paragraph presented in box 1, the excerpt from Frederick Grasett in box 2 forms two whole, distinct paragraphs - each of which opens with a clear topic sentence. ${ }^{21}$ Direction is pointed immediately: "The mode of procedure summed up is as follows"; "In all operation cases in which the skin is unbroken this is the mode of procedure, but in accidental wounds ...". His sentences are generally rightbranching: the reader knows at the outset both their subject and where they will lead. Unlike Lister's writing, too, the reader can follow the line of thought without detouring through frequent afterthoughts. Furthermore, despite the length of Grasett's second sentence, its series of short clauses describing the process relentlessly carries the reader forward: "The skin being cleansed, the fingers of the surgeon and assistants, sponges, knife, and all instruments used purified; the spray is turned on, the opening made, the pus evacuated, any bleeding vessel secured by a carbolized catgut ligature,

Admittedly, Grasett's discussion concluded an address outlining the theory behind antiseptic surgery and did not offer explicit instructions of the general process, but his explanation nevertheless is straightforward and chronological. His parenthetical statements do not interrupt the flow of thought or appear to second-guess an action: they are inserted to explain the reason for it. Not only does the simile in one use an apt image"otherwise it would glide off the silk like water off a duck's back"-but word choice throughout the excerpt is definitive. An assistant should do this; the dressing is raised; the drainage tube is removed; and so on. Grasett also provides precise information: "washed in 1-40 lotion", how intervals lengthen for dressing changes, the kind of drainage tubing to use. Finally, he uses the first person to involve his readers in the process: "we have to remember that septic matter has gained admission to 
Table 1 Stylistic statistics for three published descriptions of medical procedures

\begin{tabular}{llllll}
\hline $\begin{array}{l}\text { Author of } \\
\text { description }\end{array}$ & $\begin{array}{l}\text { Words } \\
\text { (n) }\end{array}$ & $\begin{array}{l}\text { Sentences } \\
\text { (n) }\end{array}$ & $\begin{array}{l}\text { Average } \\
\text { words per } \\
\text { sentence }\end{array}$ & $\begin{array}{l}\text { Maximum } \\
\text { words per } \\
\text { sentence }\end{array}$ & $\begin{array}{l}\text { Average } \\
\text { word length } \\
\text { (letters) }\end{array}$ \\
\hline Lister & 358 & 7 & 51 & 74 & 5 \\
Grasett & 446 & 9 & 50 & 92 & 5 \\
Roddick & 290 & 9 & 32 & 68 & 5 \\
\hline
\end{tabular}

the wound before we saw it, and we have to endeavor to correct it."

In box 3, the excerpt from Thomas Roddick opens even more dramatically in the first person: "I proceeded as follows". ${ }^{22}$ Like Grasett, he signals the direction and purpose of his discussion, to present his method of employing the antiseptic method of treatment in a specific case, "Case I: Compound Fracture of the Bones of the Tarsus, involving the Ankle-joint.-Amputation". This case forms one of several in which he used, and reported on his use of, antiseptic dressings in Montreal. Roddick's account continues in the first person, allowing him to write actively and definitively: I injected, I washed. Like Grasett, too, he provides precise information - the largest size (No. 1) drainage tube, the one-to-twenty solution. Partly owing to the purpose of his writing, Roddick also writes shorter sentences.

\section{LISTER'S SCIENTIFIC STYLE IN PRIVATE DISCOURSE}

Unlike his followers, Lister attempted to convey his own ideas, not translate them for others. But even given the difficulty of articulating one's own thought processes, Lister's style in public discourse was clumsy compared with that of his followers: his nested thoughts and tentative tone interfere with the reader's comprehension and persuasion.

It is equally clear, however, that Lister could adopt a different register for private discourse, allowing him to write effectively. Fisher notes, for example, that he wrote succinctly for his own application to a university chair (p146). ${ }^{4}$ To understand the complexity of his communication difficulty, it is therefore useful to compare Lister's scientific style in letters with that in his publication. This approach is possible because his letters typically focused on his work: "Nowhere", declared one biographer, "can there be found a letter displaying the originality of thought or feeling on any subject lying outside the sphere of surgery" (Walker, ${ }^{18}$ p94). In keeping with this view, examples of similar kinds of instructions for antiseptic dressings appear in Lister's letters to his subordinates. Box 4 shows an excerpt from a letter to another Canadian, his house surgeon Archibald Malloch ${ }^{\mathrm{i}}$ (Godlee, ${ }^{14}$ pp219-21).

The contrast between Lister's published writing and this private letter to Malloch is starkly apparent. About the same number of words, this excerpt comprises one paragraph, composed of 16 sentences (compared with seven in box 1). The maximum number of words per sentence is still high at 77 , but there are no syntactical knots. Instead, his one long sentence is clearly punctuated with colons that function as full stops, providing direction and progression: change these colons to full stops, and you reduce the maximum words per sentence to 44. Lister writes clearly, deliberately, succinctly, outlining the

\footnotetext{
i For the purposes of this discussion, we have used letters published in the biography written by Lister's nephew, Sir Rickman John Godlee, who lived and trained with Lister for many years and also had access to his notebooks. Even if their representation deviates from the original document, these letters usefully demonstrate a contrast in style and register from Lister's other writing.
}

process chronologically. He provides signposts along the way (First, then). He speaks directly to his reader: "The mode of doing it would be as follows." In addition to using first person, Lister also uses concrete nouns throughout his description, some of them describing common household items (wash house boiler, frying-pan, large sauce-pan). His verbs are definite, active, and imperative: rub off, place, sprinkle, is to be left, you will find. Little is left to the discretion of the reader-except for common sense-and so there are few modal auxiliary verbs. He provides exact information, even when it is the well-known boiling point of water $\left(212^{\circ}\right)$. His parenthetical statements are informal definitions ("it is a bright red powder, used as a pigment") or explanations ("If you use chloroform the adhesiveness is greater.") Also, in this genre he has the advantage of providing a physical example by way of illustration: "I enclose a specimen to show you what you are to produce." As this excerpt alone indicates, then, Joseph Lister was fully capable of explaining his methods in writing.

The difference in register as he wrote personally to a subordinate accounts in part for his facility here. However, consideration of Lister's style in letters to a scientific superior suggests that other, rhetorical reasons were at play in his communication difficulties with colleagues. As he developed his theory of antiseptic surgery and struggled with its early communication to colleagues, Lister corresponded weekly with his father, J J Lister. The formal stance that he adopted in these letters reflected deference not just to a father, but, more importantly, to both their Quaker faith and his father's recognised scientific stature.

Lister described some of his cases to his father in the same laborious manner that carried over to his published work. Indeed, although J J Lister had encouraged publication, Lister concentrated on his clinical cases using carbolic acid: "Meanwhile I almost long to be writing it, as it promises to be at least as satisfactory as Part I, and very likely as long", he wrote to his father in February 1867, but "Cases to illustrate it are now accumulating, and hardly a day passes without some new fact turning up regarding it" (Godlee, ${ }^{14}$ p186). When Lister was developing his seminal paper for The Lancet, his father suggested that their prominence was directing the reader away from the underlying principle (Godlee, ${ }^{14}$ p189), but evidently to no avail: Lister preferred to present his cases-and his thinking-as they unfolded in a kind of stream-of-consciousness narrative.

In a lament no doubt familiar to clinical faculty today, Lister explained that he had enough for three people to do and that what he wanted to do remained undone: "Preparation for the Lancet would do for one individual; practice, hospital and private, would be amply sufficient for a second; and College duties, including looking over the answers of the students to a class examination, together with correspondence, would do well for a third person." He felt "forced" each day to give his lecture and tend his patients: "And if thee were in my place," he told his father, "thee would, I suspect, feel as I do, that the latter is the most pressing of all" (Godlee, ${ }^{14}$ p217). For this reason, he continued, he would investigate anything that would improve his patients' care (Godlee, ${ }^{14}$ pp217-18).

Again, Lister's published writing and this private letter contrast dramatically in style and register (box 5). Unlike the example from Lister's letter to Malloch, this excerpt forms only part of a paragraph. However, it begins the description clearly: "It is this." The description of the putty dressing then follows a syntactical pattern more akin to that found in his letter to Malloch than to that in his published writing (table 2). 


\section{Box 4: Joseph Lister's private writing}

I enclose a specimen to show what you are to produce. The mode of doing it would be as follows. First with the dry finger rub off the film of gutta percha from a portion of your lac plaster of any suitable size, say a foot square: and place the plaster (lac upwards) upon a metal plate (say a piece of tin) and sprinkle over the surface of the lac some "red lead" (this, if not in the laboratory, can be got from any chemist or painter: it is a bright red powder, used as a pigment). The powder should be diffused pretty uniformly, which can be done readily enough with a camel's hair brush. But, provided the whole surface is covered, it is of no consequence whether the layer is a little lumpy or not. A thin layer is enough, but a little additional thickness does no harm. Then place the tin on the top of some vessel containing boiling water. I dare say the wash house boiler would do well; the tin being placed upon the cover of the boiler, if the cover is metallic: otherwise a plate of iron should be put on instead of the cover (supposing the cover to be of wood). Or a frying-pan, or large sauce-pan would do, the tin plate being put directly over the vessel. This, however, you will do as common sense may dictate. The plaster is to be left at the temperature of $212^{\circ}$ (or near it) for a few minutes, say five. The tin plate is then removed and placed where it may cool rapidly. When it is cool, the superfluous red lead is brushed off, and the process is complete. You will find the remaining lead is incorporated, so that it cannot be washed off by water. When, however, you wish to use it for compound fracture, etc., you can wash away the lead by a small cloth dipped in spirit of wine, or still better, chloroform, and you will find the plaster restored to its original adhesiveness, or even more. (If you use chloroform the adhesiveness is greater.) (Joseph Lister to Archibald Malloch, 10 September 1868. Source: Godlee, ${ }^{14}$ pp219-21.)

Not only are there fewer words per sentence and more sentences, but Lister similarly uses first person, exact measurements, parenthetical definitions or explanations ("else it would confine the discharge"; "such as is used for the Paraffine candles"; "Paraffine has only about $2 / 3$ the specific gravity of water"), and concrete nouns that again refer to common household ingredients. Here, too, he provides emphasis through italics (probably underlining) and a list of ingredients. Unlike his letter to Malloch, this one does not propose to provide instructions; however, the logical progression of his thinking is clear. First, he discusses the problem; then, he offers his solution: "But I seem to have succeeded with the following." The recipe for the solid form of putty is then carefully presented in a fashion easily followed by a medical colleague. Lister then writes very personally, with almost boyish wonder at the results obtained: "Well, this acts most beautifully. It is really astonishing how thin a layer will keep the discharge perfectly sweet."

Here, Lister speaks directly to his reader and provides didactic explanations. His reader is well known to him; he is one individual whom he can visualise and feel secure in outlining his method to. Examples of his different register-and ethos-can be multiplied from other letters to his father that focus less on the procedure and more on the unexpected results: on 17 March 1867, he exclaimed "Well, I opened it on the new plan 4 days ago, taking out just a pound of pus, and to-day the whole discharge of 28 hours was three quarters of a drachm, quite odourless, and almost transparent!" (Godlee, ${ }^{14}$ p187). On 5 July 1868, he explained:

\section{Box 5: Lister's writing in a private letter to his father}

In the course of last week such a thing has occurred, which I almost hesitate to mention to thee, lest thee should think I ought to have been writing instead of working at it. But I do not like to keep it from thee. It is this. The putty having proved itself quite trustworthy, whereas a thick folded cloth soaked with an oily solution of carbolic acid is not trustworthy, although containing much more of the acid, but the putty having various practical inconveniences, such as its weight; I endeavoured to obtain a means of getting the advantages of the putty without its disadvantages. The efficacy of the putty evidently depends upon its impermeability to the discharge; which is shed by it instead of penetrating into its substance as it does into that of a cloth. Hence it seemed that if the oily material in which the acid is dissolved could be got in a solid form, there would be no need of the heavy whitening, which is only used to give consistence to the material, and yet constitutes five sixths of its weight. To procure a solid fat fit for the purpose proved no easy matter. It must be of just the right firmness, not melting at the temperature of the body, and not adhering to the surface of the skin (else it would confine the discharge). But I seem to have succeeded with the following. Paraffine (such as is used for the Paraffine candles), which does not melt with the warmth of the body and is not adhesive, is the basis. To give it tenacity I add a little wax, and to give sufficient softness a little olive oil.

$\begin{array}{ll}\text { Paraffine } & 6 \text { parts. } \\ \text { Wax } & 2 " \\ \text { Olive oil } & 1^{\prime \prime}\end{array}$

Carbolic acid 1 or $1 / 2$ or $1 / 4$, etc. according to the purpose. Well, this acts most beautifully. It is really astonishing how thin a layer will keep the discharge perfectly sweet. And not only a thin layer, but a comparatively small amount of surface; answers the purpose. And the dressing being peculiarly light (Paraffine has only about $2 / 3$ the specific gravity of water) all the inconveniences of the putty are got rid of, along with superior efficiency for some situations, as the new paste can be applied to parts to which it was impossible to apply the putty satisfactorily. (Joseph Lister to Joseph Jackson Lister, 8 March 1868. Source: Godlee, ${ }^{14}$ pp217-18.)

\footnotetext{
Three days ago I had a nice case for the antiseptic treatment, a "loose cartilage" in the knee joint, 11/4 inch long by 1 inch broad and $1 / 4$ inch thick: the largest I ever saw ... I removed it by a free incision into the knee joint!! a thing I should not have thought of doing without the antiseptic system. I had carbolic oil dropped on the wound as I cut, and drew out the cartilage under cover of an antiseptic rag and dressed with the plaster ... . To-day the discharge is about one drop for 24 hours. So we may say it has been a complete success (Godlee, ${ }^{14}$ pp210-11).
}

As these passages illustrate, had Lister used letters to his father as drafts for his scientific publication, by removing the exclamation marks alone he would have achieved an appropriate tone while improving the coherence of his method.

Instead, for his wider, faceless readership, Lister was unable to adopt such a modified conversational approach as exemplified by his followers. His letters thus throw into relief a problem with ethos, the rhetorical concept referring to the character or reputation of the author conveyed implicitly or subtly throughout the discourse. Lister was able to communicate naturally and easily with those who knew him, both subordinate and superior, relying on his ethos as experienced and confident but humble surgeon. Although we can only 
Table 2 Stylistic statistics of two of Joseph Lister's manuscript descriptions

\begin{tabular}{llllll}
\hline Letter & $\begin{array}{l}\text { Total } \\
\text { words }\end{array}$ & $\begin{array}{l}\text { Total } \\
\text { sentences }\end{array}$ & $\begin{array}{l}\text { Average } \\
\text { words per } \\
\text { sentence }\end{array}$ & $\begin{array}{l}\text { Maximum } \\
\text { words per } \\
\text { sentence }\end{array}$ & $\begin{array}{l}\text { Average word } \\
\text { length (letters) }\end{array}$ \\
\hline To Malloch & 352 & 16 & 22 & 77 & 4 \\
To J J Lister & 385 & 19 & 20 & 57 & 5 \\
\hline
\end{tabular}

speculate about his perception of ethos, his letters imply his belief that a different ethos was required in a public forum. In his publications, he clearly spotlighted his humility and uncertainty over his knowledge and experience. Shy and acutely aware of himself, of his stature as newcomer in the scientific community, and of the novelty of his methods-especially the theory on which they rested-Lister perhaps overcompensated by attempting to convince solely through reason (logos), rather than through a combination of logical and ethical appeals.

Corroborating these inferences are the reactions of other modern readers. The two excerpts of Lister's writing in boxes 1 and 4 have been both presented and assigned to working professional students in graduate biomedical communication courses within the past few years. The only background information these students sometimes received, depending on the course, was the article on semantic bypassing in Lister's work; this essay provided them with some historical context for the kind of prose they were about to examine. Trained in clinical subjects and often employed as medical writers and editors, their informed views on contemporary medical discourse gave further insight into Lister's style: as students independently parsed Lister's tortuous sentence structure in box 1 , they identified semantic and punctuation markers suggesting that his article either was a transcript of an oral presentation or was hastily drafted from one; they noted its resemblance to a narrative; they suggested he seemed reluctant to say things in print, evaluated his ethos and even (unwittingly) detected evidence of his stammer in his use of assonance.

Students were asked specifically to provide traditional stylistic analyses of box 1 with reference to syntactical, lexical and rhetorical features. In one course, they also shared their analyses, leading to animated discussion. With respect to syntax, while recognising trends in English and scientific communication, students consistently maintain that Lister's sentences are too long. Sentences are long not because of polysyllabic medical jargon but because they have too many interruptions and he uses too many words. Semantically, they feel his overuse of vague terms-especially qualifiers such as very, so-implied that Lister had not thoroughly practised his procedure before writing it up. How large a border of sound skin constitutes "a very considerable distance", they ask? They trip over his verb tenses and want more definitive or aggressive forms (changing should to must, for example). Rhetorically, some have inferred nervousness in his rambling, vague style and a possible intent to draw readers into his thinking about a novel theory rather than merely recounting a procedure. In short, these modern readers react to Lister's presentation in such a way as to feel for him: they, retrospectively, know he had something to say but marvel at his struggle to say it.

\section{CONCLUSIONS}

This study refines our understanding of Joseph Lister's style of communication from earlier biographies and studies. Using stylistic and rhetorical analyses from four perspectives (including comparing our inferences with that of other readers), it reveals important features of this historical example of medical discourse. First, Joseph Lister was not consistently a poor communicator. He wrote with facility in private discourse such as a letter to a student, a young man whom he knew well and could visualise in a fatherly way: here, Lister's writing was in all respects clear, concrete, concise and informative. In such a letter, he wrote to teach. He wrote with equal facility in letters to a mentor, his father. In all his letters to J J Lister, he wrote to report and seek advice-both, again, informational rather than persuasive functions.

Second, Lister's perception of ethos deeply and adversely affected his public discourse. This discourse needed to persuade. He clearly understood that the appropriate ethos for formal scientific communication to colleagues was detached and neutral; however, unable to visualise his audience and possibly fearing negative reactions from colleagues and superiors, Lister seems to have strained so hard to achieve an appropriate ethos that he rendered his writing awkward and unnatural. Lister may have also redoubled his effort to appear humble in the light of both his Quaker faith and his father's scientific profile. Both these possibilities require further exploration within the context of the strong Quaker scientific tradition in that period. However, The Chief, an 1873 poem about Lister by W E Henley, a former patient at the Edinburgh Infirmary, perceptively captured the conflicted ethos of this shy man who yet battled custom and prejudice in medicine. He had a complex communication role to fill as a surgeon, not a scientist: upholder of his family name and tradition, demonstrator of professional demeanour in scientific discourse and supporter of a new, revolutionary theory of disease causation by germs. The role of being Lister may have weighed so heavily on him that he retreated further into humility than any one of these roles would have demanded. Ironically, his ethos was then interpreted by some readers as egotistical: who was this man, they wondered, who claimed to have developed something new when we all know the value of carbolic acid?

These analyses remain suggestive owing to the limited sampling from Lister's published (and, perhaps, edited) writing. Nevertheless, even these brief comparisons highlight the contingent and complex nature of communication in general and contribute to our broader understanding of medical communication in particular. Scholarship on written medical discourse in clinical practice has tended to emphasise the case report; owing to their literary training, many investigators are drawn especially to study the narrative form of this genre. ${ }^{23-30}$ Recent work has elevated this approach to a more abstract discussion of genre theory. ${ }^{31}$ Medical communication has otherwise been investigated in narrow rhetorical and linguistic areas. $^{32-38}$ Although these areas delineate some contours of the subject through broad strokes, work on the nature of medical authorship remains patchy,,$^{40}$ and the writing of individual medical innovators has not yet attracted the kind of scrutiny seen in studies of individual scientists such as Francis Bacon, Isaac Newton, Joseph Priestley, Thomas Huxley, James Watson and Francis Crick. ${ }^{41-44}$ We also await sophisticated studies of medical publications, like those that have been undertaken for scientific works. ${ }^{24} 4546$

For medical communication, the case of Joseph Lister thus illustrates that ideas can persuade and endure thanks to modes of discourse other than the written. ${ }^{47}$ It also suggests that problematic written discourse offers a useful heuristic device for stylistic analysis and for classroom discussion of medical narrative. As a nuanced example in which the successful uptake of a new medical idea happened despite its inarticulate 
representation, the case of Lister augments our limited understanding of medical practitioners who encountered difficulties when attempting to convey revolutionary ideas.

For example, recent studies of Dr Frederick Banting and Dr Barry Marshall indicate that these 20th-century medical practitioners were rhetorically ill-prepared when they tried to communicate to the scientific community. Banting, and his coauthor Charles Best, displayed "an almost damaging degree of humility" in their first publication on pancreatic secretion (Trott, ${ }^{48}$ p53). It was the superior ethos of a senior colleague, J J R Macleod, that later convinced the scientific community of the merit of the research. At the same time, they reflected a certain hubris in dismissing the work of earlier researchers, and it was hubris that appears to have adversely affected Marshall's style: his was not a possible answer to a long-standing scientific question, but the only answer. Indeed, Marshall demonstrated so much enthusiastic naïveté-especially when he drank a solution of bacteria to induce a stomach ulcer in himself - as to fail to convince scientists that he was anything but an amateur. Consequently, it took a decade for his novel concept to be accepted: that bacteria can live in stomach acid and that they also cause ulcers. ${ }^{49}$ Medical practitioners of earlier centurieslike Lister, trained in classics, still deeply connected to religious faith-were more likely to prostrate themselves before their peers, as with the 17th-century discoverer of the circulation of blood, William Harvey, who was sufficiently aware of potential turmoil over it that he both delayed publishing and developed his argument cautiously to embed his revolutionary idea in chapter 8 of his treatise. ${ }^{50}{ }^{51}$ In short, the writer's struggle with appropriate ethos underlies these studies of medical innovators. The humility/hubris dichotomy prevalent in these cases emphasises that Joseph Lister was neither a unique nor even a pivotal figure in the history of medical writing, but rather that he shares with other medical practitioners an inadequate preparation for scientific authorship.

Acknowledgements: We are grateful to students in the Graduate Program in Biomedical Writing at the University of the Sciences in Philadelphia, who analysed and commented on the two excerpts of Lister's writing in various courses from 2000 to 2004. The most extensive and animated discussion took place in the course BW 702 Stylistics and Editing.

Competing interests: None declared.

\section{REFERENCES}

1. Henley WE. The Chief. Quoted in: Godlee RJ. Lord Lister. 3rd edn. Oxford: Clarendon Press, 1924:609.

2. Granshaw L. 'Upon this principle I have based a practice': the development and reception of antisepsis in Britain, 1867-90. In: Pickstone JV, ed. Medical innovations in historical perspective. Macmillan: Houndmills, 1992:17-46.

3. Lawrence C, Dixey R. Practising on principle: Joseph Lister and the germ theories of disease. In: Lawrence, C, ed. Medical theory, surgical practice: studies in the history of surgery. London: Routledge, 1992:153-215.

4. Fisher RB. Joseph Lister 1827-1912. London: Macdonald \& Jane's, 1977.

5. Connor JJ, Connor JTH. Semantic bypassing in technical communication: the historical case of antiseptics. IEEE Transactions on Professional Communication 1988;31:13-7 (reprinted Technostyle 1994;11(3/4):59-69).

6. Connor JTH. Listerism unmasked: antisepsis and asepsis in Victorian Anglo-Canada. J Hist Med Allied Sci 1994;49:207-39.

7. Worboys M. Spreading germs: disease theories and medical practice in Britain, 1865-1900. Cambridge: Cambridge University Press, 2000.

8. Banta HD. Embracing or rejecting innovations: clinical diffusion of health care technology. In: Reiser SJ, Anbar M, eds. The machine at the bedside: strategies for using technology in patient care. Cambridge: Cambridge University Press, 1984:65-92.

9. Stanton J, ed. Innovations in health and medicine: diffusion and resistance in the twentieth century. London: Routledge, 2002.

10. Schlich T, Tröhler U, eds. The risks of medical innovation: risk perception and assessment in historical context. London: Routledge, 2006.
11. Bracegirdle B. The microscopical tradition. In: Bynum WF, Porter R, eds. Companion encyclopedia of the history of medicine. Vol I. London and New York: Routledge, 1993:102-19.

12. Leeson JR. Lister as I knew him. London: Baillière, Tindall and Cox, 1927.

13. EPS [Scarlett E]. In praise of Lister. Calgary Associate Clinic Historical Bulletin 1939;4:9-12.

14. Godlee RJ. Lord Lister. 3rd edn. Oxford: Clarendon Press, 1924.

15. Thomson StC. A house-surgeon's memories of Joseph Lister. Ann Med Hist 1919:2:93-108.

16. Dukes C. Lord Lister (1827-1912). London: Leonard Parsons, 1924

17. Guthrie D. Lord Lister: his life and doctrine. Baltimore: Williams and Wilkins, 1949

18. Walker K. Joseph Lister. London: Hutchinson, 1956.

19. Cameron HC. Lord Lister 1827-1912: an oration. Glasgow: James MacLehose and Sons, 1914.

20. Lister J. The collected papers of Joseph, Baron Lister. 2 vols. Oxford: Clarendon Press, 1909 (reprinted 1979)

21. Grasett FLeM. Antiseptic surgery. Canada Lancet 1876;9:99-104.

22. Roddick TG. Antiseptic dressing in surgery. Canada Medical and Surgical Journal 1878;6:241-8.

23. Solomon Watson M. The rhetoric of dehumanization: an analysis of medical reports of the Tuskegee Syphilis Project. In: Reverby SM, ed. Tuskegee's truths: rethinking the Tuskegee syphilis study. Chapel Hill: University of North Carolina Press, 2000:251-65.

24. Hunter KM. Doctors'stories: the narrative structure of medical knowledge. Princeton: Princeton University Press, 1991.

25. Flood DH, Soricelli RL. Development of the physician's narrative voice in the medical case history. Lit Med 1992;11:64-83.

26. Nowell-Smith H. Nineteenth-century narrative case histories: an inquiry into stylistics and history. Can Bull Med Hist 1995;12:47-67.

27. Greenhalgh T, Hurwitz B, eds. Narrative based medicine: dialogue and discourse in clinical practice. London: BMJ Books, 1998.

28. Taavitsainen I, Pahta P. Conventions of professional writing: the modern medical case report in a historical perspective. Journal of English Linguistics 2000;28:60-76.

29. Spafford MM, Schryer CF, Mian M, et al. Look who's talking: teaching and learning using the genre of medical case presentations. Journal of Business and Technical Communication 2006;20:121-58.

30. Hurwitz B. Form and representation in clinical case reports. Liter Med 2006;25:216-40.

31. Barton E. Introduction to the special issue: the discourses of medicine. Journal of Business and Technical Communication 2005;19:245-8.

32. Connor JJ. Self-help medical literature in nineteenth-century Canada and the rhetorical convention of plain language. Journal of Technical Writing and Communication 1994;24:265-83.

33. Connor JJ, Connor JTH. Thomsonian medical literature and reformist discourse in Upper Canada. Canadian Literature 1991;131:140-55.

34. Harley D. Rhetoric and the social construction of sickness and healing. Soc Hist Med 1999; 12:407-35

35. Lankamp RE. A study on the effect of terminology on L2 reading comprehension: should specialist terms in medical texts be avoided? Amsterdam: Rodopi, 1988.

36. Segal JZ. Strategies of influence in medical authorship. Soc Sci Med 1993;37:521-30.

37. Segal JZ. Writing and medicine: text and context. In: Spilka R, ed. Writing in the workplace: new research perspectives. Carbondale: Southern Illinois University Press, 1993:84-97.

38. Vihla M. Medical writing: modality in focus. Amsterdam: Rodopi, 1999

39. Biagioli $\mathbf{M}$. The instability of authorship: credit and responsibility in contemporary biomedicine. FASEB J 1998;12:3-16.

40. Burton H. 'Still in process': collaborative authorship in a twentieth-century biomedical textbook. Can Bull Med Hist 1995;12:373-84.

41. Stephens J. Francis Bacon and the style of science. Chicago: University of Chicago Press, 1975.

42. Bazerman C. Shaping written knowledge: the genre and activity of the experimental article in science. Madison: University of Wisconsin Press, 1988.

43. Bazerman C, Paradis J, eds. Textual dynamics of the professions: historical and contemporary studies of writing in professional communities. Madison: University of Wisconsin Press, 1991.

44. Gross AG. The rhetoric of science. Cambridge, Massachusetts: Harvard University Press, 1996.

45. Gross AG, Harmon JE, Reidy M. Communicating science: the scientific article from the 17th century to the present. New York: Oxford University Press, 2002.

46. Biagioli M, Galison P, eds. Scientific authorship: credit and intellectual property in science. London: Routledge, 2003.

47. Connor JJ. History and the study of technical communication in Canada and the United States. IEEE Transactions on Professional Communication 1991;34:3-6.

48. Trott C. Rhetorical invention in the discovery of insulin. Technostyle 2000;16:52-64

49. Penrose AM, Katz SB. Writing in the sciences: exploring conventions of scientific discourse. Boston: Pearson Custom Publishing, 2001.

50. Connor JTH, Connor JJ. Rhetorical analysis of William Harvey's De motu cordis (1628): a commentary. Journal of Technical Writing and Communication 1992;22:195-201.

51. Connor JJ. Medical text and historical context: research issues and methods in history and technical communication. Journal of Technical Writing and Communication 1993;23:211-32. 